\title{
“Lewend en kragtig"? Die hermeneutiese dinamika en implikasies van (her)interpretasie in die Ou Testament
}

\begin{abstract}
"Alive and active"? The hermeneutic dynamics and implications of (re) interpretation in the Old Testament
\end{abstract}

Biblical interpretation remains a contentious matter. Not only are there regularly fierce debates in church circles on how the Bible should be interpreted on issues of dogma and ethics, but even the letter columns of newspapers and chatrooms on the internet are often full of discussions on all aspects of biblical interpretation. These debates cover the whole spectrum of opinions ranging from those who insist on the factual accuracy and credibility of the Bible and who cling to this belief with a passionate conviction as a guide to doctrine and to life, to those who think that the Bible no longer has any value in a scientific age and that it should therefore be rejected as a source which has any authority. In these debates there is not much room for nuance.

The conviction is expressed in this article that a study of how interpretation is undertaken in the Bible could open up important perspectives on the difficult questions of the interpretation of the Bible in our own time. In addressing the issue of interpretation in the Bible this article concentrates on the Old Testament, the field of specialisation in biblical scholarship of the author. The study starts with an overview of the research done in the discipline of Old Testament studies on the phenomenon of inner-biblical interpretation. In a subsequent section the phenomenon of inner-biblical interpretation is illustrated with reference to research on the books of Chronicles. This survey and the illustrations are followed by a section in which the hermeneutic implications of the dynamics of (re)interpretation in the Bible are spelled out for theology and the church. In the conclusion the article returns to the questions posed in the introduction.

Bybelinterpretasie bly 'n omstrede saak. Nie net vind daar gereeld hewige debatte in kerklike geledere plaas oor hoe die Bybel geïnterpreteer moet word oor sake van dogmatiese en etiese belang nie, ${ }^{2}$ maar selfs die briewekolomme van dagblaaie ${ }^{3}$ en gesprekruimtes op die internet ${ }^{4}$ is

\footnotetext{
1 'n Verkorte weergawe van hierdie artikel is op 31 Maart 2011 deur die outeur as professorale intreerede gelewer.

2 Een prominente voorbeeld wat vanuit NG Kerk-kringe genoem kan word, is die debat oor homoseksualiteit, en veral of homoseksuele persone in die amp van predikant mag dien.

3 Dit blyk dat dit veral in Afrikaanse dagblaaie is waar die debat telkens weer opvlam en hewig woed.

4 LitNet (http://www.litnet.co.za) blyk 'n gewilde ruimte te wees wat deur oorwegend Afrikaanssprekende deelnemers benut word. 'n Indringende debat in hierdie verband wat 'n tyd gelede op LitNet plaasgevind
} 
dikwels gevul met gesprekke oor allerlei aspekte van Bybelinterpretasie.

Hierdie debatte dek 'n spektrum van standpunte wat strek vanaf diegene wat op die feitelike korrektheid en geloofwaardigheid van die Bybel aandring en wat met vurige geloofsoortuigings daaraan wil bly vashou as 'n riglyn vir leer en lewe, tot diegene wat meen dat die Bybel geen waarde meer het in 'n wetenskaplike eeu nie en dat dit daarom verwerp moet word as 'n bron van enige gesag. ${ }^{5}$ Vir nuanse is daar nie veel ruimte in hierdie debatte nie.

Die kernvraag wat in hierdie konteks aan ons opgedwing word - aan Bybelwetenskaplikes, teoloë en ander gelowige Bybellesers tegelyk - is of 'n mens werklik nog in die taal van 'n Nuwe-Testamentiese skrywer in Hebreërs ${ }^{6}$ 4:12 kan bely: "Die woord van God is lewend en kragtig"? 7 Of is die Bybel dalk maar net 'n klassieke versameling tekste ${ }^{8}$ uit vervloë tye wat soos 'n museumstuk eerbiedig moet word, of klakkeloos in ons godsdienstige rituele en liturgieë, en ons teologieë, herhaal moet word?

Ek wil vir 'n oomblik hierdie vrae oor die interpretasie van die Bybel in die lug laat hang, voordat ek aan die einde van my lesing weer daarna sal terugkeer. Ek wil my in die grootste deel van hierdie lesing egter daartoe wend om eerder te praat oor interpretasie in die Bybel. My oortuiging is dat ' $n$ studie van hoe interpretasie in die Bybel plaasvind, lig kan werp op die moeilike vrae uit ons tyd wat dusver in my inleiding aan die orde gestel is.

In my behandeling van die kwessie van interpretasie in die Bybel gaan ek konsentreer op die Ou Testament, my spesialisveld in die Bybelwetenskappe. Ek doen dit met die wete dat die interpretasieprosesse wat reeds in die Ou Testament - oftewel, die Hebreeuse Bybel in die Joodse tradisie - voorkom, ook beïnvloedend en rigtinggewend voortgespoel het in die NuweTestamentiese tradisies van die Christelike kerk. ${ }^{9}$ Die oorname van die Hebreeuse Bybel van die Joodse tradisie as Ou Testament van die Christelike kerk is as sodanig al ' $n$ aanduiding van die kontinuïteit wat in die Christendom tussen hierdie tradisies gesien word. Om enigsins ' $n$ aanduiding te kan gee van die soort navorsing waarin ek spesialiseer, gaan ek egter op die Ou Testament konsentreer.

Ek wil begin deur 'n oorsig te gee oor die navorsing wat in die Ou-Testamentiese dissipline oor die verskynsel van binne-Bybelse uitleg gedoen is. Na hierdie bespreking sal ek die kerninsigte opsom en die gebruikte terminologie definieer. In'n volgende afdeling sal ek dan hierdie verskynsel van binne-Bybelse interpretasie illustreer aan die hand van my navorsing oor die Kroniekboeke. Vanuit hierdie oorsig en illustrasie sal 'n afdeling volg waarin ek die hermeneutiese implikasies van die dinamika van (her)interpretasie in die Bybel vir teologie en kerk probeer uitspel. Ek sal afsluit met ' $n$ kort afdeling waarin ek sal terugkeer na die vraagstellings oor interpretasie in 'n (post)moderne konteks wat in die inleiding aan die orde gestel is.

het, is selfs ook later in tradisionele boekvorm gepubliseer. Sien MoLLETT et al. (2004).

5 Sien bv. Pelser (2005) as voorbeeld van die eerste pool, en ClaAsSen (2007) as voorbeeld van laasgenoemde. Albei hierdie outeurs neem ook gereeld deel aan die debat in die briewe- en rubriekkolomme van Afrikaanse dagblaaie.

6 Kommentatore wys deurgaans op die baie sterk Joodse wortels van die Hebreërboek. Sien bv. JoHNSON (2006:24-25).

7 Hierdie frase in Heb 4:12 volg na 'n gedeelte (3:7-4:11) waarin die Hebreërskrywer'n paranetiese uitleg van Psalm 95 gee. Eers (3:7-16) word uit hierdie psalm aangedui dat die woestyngenerasie van God se rus uitgesluit is weens hul ongeloof en rebellie. Daarná $(4: 1-11)$ word dieselfde psalm herinterpreteer vir die Christengemeenskap om tot die gevolgtrekking te kom dat húlle erfgename van God se belofte van rus is. Vers $12-13$ bring dan die paranetiese gedeelte tot 'n einde deur te verklaar dat die "woord van God"

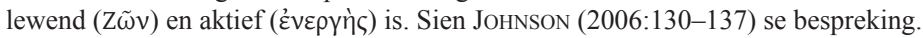

8 Sien bv. Stendahl se 1983-SBL- presidensiële rede, gepubliseer in STENDAHL (1984).

9 Sien as voorbeelde die resente studies deur Moyise $(2001 ; 2008)$. 
Hoewel daar ook tekens hiervan in vroeëre studies bemerk kan word (soos aanstons aangetoon sal word), was dit veral Michael Fishbane wat met sy 1985-publikasie Biblical Interpretation in Ancient Israel ${ }^{10}$ die aandag gefokus het op die verskynsel van binne-Bybelse uitleg. Uit die beskikbare oorsigte oor soortgelyke studies ${ }^{11}$ blyk dit dat daar veral twee verskillende blikrigtings is waardeur 'n belangstelling in binne-Bybelse uitleg na vore getree het. Enersyds is daar Fishbane en andere wat terugvra na die wortels van dié soort uitlegtradisies wat in die latere Joods-rabbynse omgewings gefloreer het. Fishbane stel die vraagstelling van sy boek soos volg:

[I]t has seemed fundamental to me to investigate the following questions: When did the Jewish exegetical tradition come to be formed? What literary and historical factors contributed to its birth? Is the development of and exegetical tradition in post-biblical Judaism solely the product of internal tensions - or does the Hebrew Bible also reflect the prehistory of those postbiblical phenomena whose content are so new and often 'unbiblical'?12

Fishbane kom tot die gevolgtrekking dat hierdie na-Bybelse uitlegtradisies inderdaad hul wortels in die geskrifte van die Hebreeuse Bybel het, en nie eers 'n vernuwende tendens onder invloed van die latere Grieks-Romeinse kultuur was nie. ${ }^{13}$ Hy wys dus daarop dat die dinamika van tradisie en interpretasie nie slegs 'n na-Bybelse fenomeen is nie, maar reeds duidelik in die Bybel naspeurbaar is.

Andersyds kan daar ook 'n ander blikrigting onderskei word. In tradisionele histories-kritiese navorsing wat veral in die Duitssprekende akademiese wêreld gedy het (en steeds gedy), het daar algaande in sommige kringe die insig begin ontwikkel dat die groeiprosesse van antieke Bybelse tekste nie blote kompilasies was nie, maar dat daar onderskeibare motiverings was waarvolgens vroeëre tekste hergebruik, aangepas, bevestig en selfs verander is om nuwe tekste tot stand te bring. Aangesien die diakrone belangstelling by die tradisionele histories-kritiese benaderings baie sterk is, word die Bybeltekste noukeurig ondersoek om vas te stel watter lae in 'n teks voorkom en in watter chronologiese verwantskap hierdie lae tot mekaar sou staan. Dis veral in die vertakking van die histories-kritiese benadering, wat redaksiegeskiedenis genoem word, dat die insig al sterker na vore begin tree het dat hierdie verskillende lae nie die blote neerslag van historiese groeiprosesse is nie, maar inderdaad aanduidings is van onder andere diepe teologiese gesprekvoering en beredenering waardeur latere geslagte van hul oorgelewerde tradisies, maar ook van hul kontemporêre kontekste, probeer sin maak het. Hierdie blikrigting verskil dus van die eerste wat ek onderskei het in dié opsig dat die belangstelling in binne-Bybelse uitleg eerder gegroei het vanuit die diakrone onderskeiding van verskillende voorstadia in die Bybeltekste, en nie soseer deur die belangstelling in die latere na-Bybelse uitlegtradisies (soos by Fishbane en andere) nie. Hoewel ons twee verskillende blikrigtings kan onderskei, toon die eindresultaat daarvan merkwaardige ooreenstemmings.

Ek begin die navorsingsoorsig by die tweede blikrigting, naamlik die groeiende klem op binne-Bybelse uitleg wat veral in Duitssprekende Bybelwetenskap ontwikkel het. Konrad Schmid verbind in sy oorsig oor die navorsingsgeskiedenis ${ }^{14}$ die nuwe belangstelling in binneBybelse uitleg met die onbehae wat algaande in Duitssprekende kringe ontwikkel het jeens

10 Fishbane (1985). Sien ook Fishbane (1992; 1998a; 1998b; 2003; 2004).

11 Sien bv. Edenburg (2010), Reventlow (2009), LeVinson (2008a), LoAder (2008), Bautch (2007),

Sommer (2004), Schmid (2000), Tull (2000) en McKenzie (1999).

12 Fishbane (1985:2).

13 FishBANE (1985:525).

14 Sien SCHMID (2000). 
die tradisionele Literarkritik. $^{15}$ Hierdie spesialismetode wat sedert die $19 \mathrm{e}$ eeu in die stal van histories-kritiese benaderings tot die Ou Testament ontwikkel het, het veral ten doel om op grond van doeblette, spanninge en breuke wat in die tekste waargeneem kan word, teorieë te ontwikkel oor die historiese gelaagdheid van Bybeltekste. In die klassieke Literarkritik word daar dan dikwels onderskei tussen ouer en jonger teksmateriaal en latere toevoegings tot meer oorspronklike tekste. Die sogenaamde krisis in die Literarkritik, soos Schmid dit noem, ${ }^{16}$ ontwikkel egter vanweë veral twee redes. Enersyds het daar in die tweede helfte van die 19e en die eerste helfte van die 20ste eeu soveel verskillende onderskeidings ontwikkel tussen wat as ouer en jonger teksmateriaal sou geld dat eenstemmigheid oor die gelaagdheid van die tekste nie daaruit ontwikkel het nie. Andersyds is die belangstelling van die klassieke Literarkritik hoofsaaklik literêr van aard. Dit wil sê, die Literarkritik het sy taak voltooi wanneer 'n onderskeid tussen ouer en jonger materiaal in 'n bepaalde teks gemaak is. Daar word nie ook nog verder gevra na die motiverings vir die groeiprosesse in die tekste nie. Volgens Schmid het hierdie onbehae algaande daartoe gelei dat die analities-literarkritische onderskeidings aangevul is met sinteties-redaksiehistoriese teorieë. Daar word dus nie meer net onderskei tussen verskillende lae in tekste nie, daar word ook gevra na die (teologiese) motiverings wat gegeld het in die redaksieprosesse wat hierdie lae uiteindelik tot een teks saamgewerk het. Dit is in hierdie konteks dat binne-Bybelse uitleg 'n nodige aanvulling tot die tradisionele Literarkritik kon bring.

Dit is egter belangrik om daarop te wys dat hierdie motiverings nie eers in werking getree het toe skriftelike materiaal saamgewerk en geredigeer is nie. Dit word algemeen aanvaar dat 'n fase van mondelinge oorlewering ten grondslag lê van die meeste skriftelike materiaal in die Ou Testament. ${ }^{17}$ Schmid wys daarop dat die kategorie van "uitleg/interpretasie" juis ook nuwe insigte geopen het om te begryp waarom sekere mondelings oorgelewerde tradisies algaande op skrif gestel is. In 'n prominente vertakking van die histories-kritiese eksegese, naamlik die sogenaamde Tradisiekritiek, was dit veral Gerhard von Rad wat beklemtoon het dat daar in Ou Israel bepaalde mondelinge tradisiekomplekse ontwikkel het aangaande sekere kernbelydenisse wat in die geloofsgemeenskappe geleef het. ${ }^{18}$ Schmid beklemtoon dat daar dus ook algaande belangstelling ontwikkel het om hierdie oorgang tussen mondelinge tradisiekomplekse en skriftelike tekste nie net te sien as 'n meganiese ver-skrif-ting nie, maar dat daarin reeds teologiese uitlegoortuigings geïdentifiseer kan word. ${ }^{19}$

Schmid identifiseer vervolgens in sy oorsig vier nuwe insigte wat na vore begin kom het met die belangstelling in binne-Bybelse uitleg wat oor die afgelope dekade of drie ontwikkel het: ${ }^{20}$ eerstens, die metodologiese beklemtoning dat die binne-Bybelse resepsiegeskiedenis ter aanvulling van literarkritische onderskeidings moet dien; tweedens, die herwaardering van sekondêre gedeeltes in die Ou Testament wat in vroeëre studies teologies tot blote 'byvoegings' gedegradeer is; derdens, die insig dat tekste wat normaalweg redelik laat in die Persiese of Hellenistiese tydperke dateer word, ook tradisies en teologiese onderskeidings uit

15 Ek gebruik die Duitse term deurgaans om hierdie vertakking van die histories-kritiese eksegese te onderskei van "literary criticism" (literêre kritiek), wat op die sinkrone gestalte van tekste fokus.

16 SCHMID (2000:1).

17 Sien bv. die werk van CARR (2005) en VAN DER TOORN (2007).

18 Sien FishBANE (2004), waarin hy 'n aanduiding gee van die ooreenkomste en verskille tussen Von Rad se benadering en sy eie.

19 SCHMID (2000:18) dui aan dat die werk van Jörg Jeremias oor die profeteboeke ook hierdie aspek beklemtoon: "[D]arüber hinaus haben vor allem die Arbeiten von Jeremias deutlich gemacht, wie sehr der Prozess der Erstverschriftung bereits selbst Auslegungscharakter hat. Innerbiblische Schriftauslegung beginnt also nicht erst bei der redaktionellen Fortschreibung einer Grundschrift, sondern - bei Texten mit mündlichen Vorstufen - bereits beim Vorgang der Erstverschriftung".

20 SCHMID (2000:3). 
vroeëre tydperke in hulself saamdra; en vierdens, dat die groei van die Ou Testament uit ' $n$ redaksiehistoriese perspektief ' $n$ sintese tussen die deeldissiplines geskiedenis, inleiding en teologie van die Ou Testament bewerkstellig.

Met hierdie klem, soos opgesom deur Schmid, het die aandag in die eksegese algaande begin wegskuif van 'oorspronklike outeurs' na die rol van 'redaktors', van literarkritische onderskeidings na redaksiehistoriese perspektiewe. Reventlow som hierdie verskuiwing soos volg op:

In the course of the investigation of Old Testament texts, scholars have increasingly recognized that these do not represent a single stage of development but rather have behind them a lengthy history of evolution. The recognition and explication of this evolution has been the task of redaction history. This method's essential argument has been that the present form of Old Testament books is due to the activity of editors. While their work was carried out anonymously, meaning that their names are not known, traces of their activity can be demonstrated in many places in Old Testament writings. ${ }^{21}$

Wanneer Schmid dan in 'n onlangse publikasie self poog om die literêre geskiedenis van die Ou Testament te beskryf, spits hy hierdie ontwikkeling nog verder toe deur sy uitgangspunt in "Redaktion als innerbiblische Rezeption" (redaksie as binne-Bybelse resepsie) te neem. Hy stel dit soos volg:

Die Redaktion der biblischen Bücher ist kein sachlich unkontrollierter Prozess der Textvermehrung, sondern in aller Regel ein textlich produktiver Vorgang innerbiblischer Rezeption und Auslegung vorgegebenen Textguts. In den Schriften des Alten Testaments sind in der Regel Text und Kommentar vereint, erst nach dem Abschluss des Kanons tritt die Auslegung neben den Text. Redaktionsgeschichte ist als innerbiblische Rezeptionsgeschichte beschreibbar, deren Rekonstruktion die innerbiblischen theologischen Diskurslagen in ihren historischen Differenzierungen wieder zum Vorschein bringen kann. ${ }^{22}$

Om dus hierdie blikrigting op te som: Vanuit die onderskeiding van voorstadia in die ontstaan van Bybeltekste groei die insig algaande dat hierdie groeiprosesse as sodanig reeds die neerslag is van interpretasie- en uitlegprosesse in nuwe kontekste.

Dit bring ons dan nou by 'n oorsig oor navorsing oor binne-Bybelse uitleg wat vanuit 'n belangstelling in die na-Joodse tradisies gemotiveer is. ${ }^{23}$ Michael Fishbane neem sy vertrekpunt in die moderne tradisie-historiese benadering, wat veral gefokus het op die aktiewe verband tussen die verskillende tradisies in Ou Israel en hul oorlewering in verdere kontekste. ${ }^{24}$ Fishbane beskryf hierdie benadering soos volg:

Fully appreciative of the long prehistory of many of the themes, legends, and teachings now found in Scripture, and the fact that over time these deposits of tradition were adapted to new situations and combined in new ways, the practitioners of this approach ideally seek to discern the components of a tradition-complex, to trace their origins or attribution to certain locales, and to show the profoundly new meanings which result as these materials were integrated into more comprehensive units. ... The integration and reworking of many types of tradition at many different times and places ... had the result of incorporating non-Israelite and local Israelite materials into a national corpus whose telling and retelling was a new basis for cultural memory. ${ }^{25}$

Om onderskeid te tref tussen die inhoud van oorgelewerde tradisies en die proses van verdere

21 ReVENTLOW (2009:5).

22 SCHMID (2008:57).

23 'n Onlangse publikasie van Bernard Levinson ('n student van Fishbane) bevat 'n baie volledige

bibliografiese essay oor binne-Bybelse eksegese in die navorsingsgeskiedenis. Sien LEVINSON (2008a:95181).

24 Sien weer FiShBANE (2004), waarin die outeur met die werk van Gerhard von Rad in gesprek tree. 25 Fishbane (1985:6-7). 
oorlewering, gebruik Fishbane die terminologie traditum en traditio. ${ }^{26}$ Met traditum verwys hy na "(increasingly) authoritative teachings and traditions whose religious-cultural significance [was] vital and increasingly fundamental", terwyl traditio verwys na "the concern to preserve, render contemporary, or otherwise reinterpret these teachings or traditions in explicit ways for new times and circumstances". 27 Hoewel hierdie onderskeid fundamenteel is in Fishbane se vroeë werk, gee hy dáár al toe dat dit 'n uiters moeisame taak sou wees om in konkrete tekste onderskeid te probeer tref tussen traditum, dit wil sê oorgelewerde gesaghebbende tradisie, en traditio, as die herinterpretasies van daardie oorgelewerde tradisie. ${ }^{28}$ Trouens, in ' $n$ latere publikasie gee Fishbane toe dat hierdie onderskeid moontlik kunsmatig is. Hy dui aan: "[T]he Bible is only tradition [dus traditio - oorgelewerde tradisie] in form and content. ... As we now have them, we have tradition producing tradition through the mediation of a silent redaction". ${ }^{29}$

In sy 1985-werk onderskei Fishbane tussen vier verskillende soorte binne-Bybelse eksegetiese strategieë. Hy motiveer dit soos volg: "[T]he relationships between traditum and traditio have produced a manifold of literary and historical types in the Hebrew Bible, and their analysis discloses the distinctive exegetical forms and features of ancient Israelite literature and culture". ${ }^{30}$ Die eerste soort wat hy onderskei, is "scribal comments and corrections". In hierdie kategorie gaan dit oor veranderings van kleiner omvang wat in latere kontekste deur oorskrywers ("scribes") aangebring is. Hierdie kleiner veranderings is ter wille van inhoudelike opklaring gemaak, maar ook om teologiese of juridiese eenvormigheid tussen tekste te bewerkstellig. Hierdie veranderings sluit die volgende soorte in: opskrifte, titels, generiese aanduidings, afsluitings, glosse, en dies meer. Die tweede soort, naamlik "legal exegesis", het te make met die (veral) na-eksiliese pogings om oor die oorgelewerde Sinaï-tradisies te reflekteer, dit te interpreteer en selfs uit te brei en aan te vul met die oog op die nuwe sosio-politieke omstandighede na die ballingskap. Die derde soort, "aggadic exegesis", wil nie bloot (soos die tweede kategorie van "legal exegesis") die gapings in die traditum - soos dit ervaar word in 'n veranderde konteks - vul nie, maar wil juis hierdie oorgelewerde tradisies toepas en toeëien ter wille van teologiese en historiese verstaan in 'n nuwe tydsgewrig. ${ }^{31}$ Dit is veral in die profetiese literatuur dat Fishbane "aggadic exegesis" identifiseer. Fishbane se laaste soort is "mantological exegesis". Hier gaan dit veral oor die invoeging van droom- en visioenberigte, omens en orakels

26 Fishbane gee krediet aan Douglas KNIGHT (1975), wat hierdie terme in sy tradisie-historiese benadering voorgestel het. FISHBANE (1985:6, vn. 17) dui egter die volgende belangrike onderskeid aan: "Knight has used it primarily with respect to oral materials ... In the following I shall adapt these terms, with necessary modifications, to written sources". Fishbane verduidelik die onderskeid tussen tradisiegeskiedenis en binne-Bybelse eksegese verder: "The dynamic we have just reviewed between traditum and traditio, characteristic as it is of traditions in ancient Israel, is also present in inner-biblical exegesis, but with one significant shift: whereas the study of tradition-history moves back from the written sources to the oral traditions which make them up, inner-biblical exegesis starts with the received Scripture and moves forward to the interpretations based on it" (FISHBANE, 1985:7).

27 Fishbane (1985:8).

28 Dit is juis hierdie punt wat een van die vernaamste kritiekpunte van Lyle Eslinger op Fishbane se voorstel is. Sien ESLINGER (1992) asook SOMMER (1996) se reaksie op Eslinger se kritiek.

29 Fishibane (1998b:18).

30 FishBANE (1985:13).

31 Fishbane is bewus daarvan dat "legal exegesis" en "aggadic exegesis" met mekaar verwar kan word. Hy verduidelik die verskille breedvoerig in die inleiding tot sy derde afdeling, en som dit dan daarná soos volg op: "Legal exegesis and aggadic exegesis thus illumine different facets of a text's inherent possibilities: the one, legal exegesis, shows how a particular law can be clarified and reinterpreted qua law; while the other, aggadic exegesis, characteristically shows how a particular law (or topos, or theologoumenon) can transcend its original focus, and become the basis of a new configuration of meaning" (FISHBANE, 1985:283). 
ten einde die vertraging in die vervulling van profetiese uitsprake te probeer verduidelik.

Aan die einde van sy studie kom Fishbane dan tot die volgende gevolgtrekking:

[T] he texts and traditions, the received traditum of ancient Israel, were not simply copied, studied, transmitted, or recited. They were also, and by these means, subject to redaction, elucidation, reformulation, and outright transformation. Accordingly, our received traditions are complex blends of traditum and traditio in dynamic interaction, dynamic interpenetration, and dynamic interdependence. They are, in sum, the exegetical voices of many teachers and tradents, from different circles and times, responding to real and theoretical considerations as perceived and as anticipated. ${ }^{32}$

Fishbane se werk oefen steeds uitgebreide invloed uit in Ou-Testamentiese eksegese en Joodse studies, $^{33}$ maar vind selfs ook neerslag in sekere benaderings tot die Nuwe-Testamentiese gebruik van die Ou Testament. ${ }^{34}$ Soos hierbo genoem, is daar egter ook kritiek op Fishbane se benadering uitgespreek. Lyle Eslinger beweer, byvoorbeeld, dat Fishbane se diakrone benadering (d.w.s. dat 'n tydsverloop veronderstel word tussen ouer en jonger teksmateriaal) in wese verdag is, omdat dit sterk op sekere historiese aannames berus. Eslinger stel dus voor dat binne-Bybelse eksegese eerder vervang moet word met ' $n$ meer sinkrone benadering wat as sodanig oriënteer aan, wat hy noem, "inner-biblical allusion". Hy stel dit soos volg:

An alternative study, one that avoids these difficulties, is to study i.b.e. [inner-biblical exegesis] as i.b.a. [inner-biblical allusion]: as allusions and as biblical intertextuality. In the case of the former there should be some literary reason to assume a vector of dependence; in the latter, there is none and we must come at the semantics of the relationship from both ends (texts). ${ }^{35}$

Benjamin Sommer, in sy reaksie op Eslinger, vind egter die onderskeid wat Eslinger maak tussen "allusion" en "intertextuality" onbevredigend. Sommer reageer soos volg:

The terms allusion and intertextuality are not entirely compatible. 'Allusion', as used by literary critics, does posit an earlier and a later text, so that the study of allusion necessarily involves a diachronic component. 'Intertextuality', as most literary critics use the term, focuses on manifold linkages among texts or on connections in which the text exists. These connections do not arise exclusively from an intentional and signalled use of an earlier text, such as citation (which might be studied under the rubric of influence and allusion). Rather, they also result from the way a text reflects its linguistic, aesthetic, or ideological contexts; other texts may share those contexts, and hence readers may notice links among many texts, whether the authors of the texts knew each other or not. Thus an intertextual approach differs markedly from approaches concerned with 'influence' and 'allusion'. Intertextuality is concerned with the reader or with the text as a thing independent of its author, while an approach oriented towards allusion is concerned with the author as well as the text and reader; the study of intertextuality is synchronic, the analysis of allusion diachronic or even historicist; intertextuality is interested in a wide range of correspondences among texts, allusion with a more narrow set; intertextuality examines the relations among many texts, while allusions represent specific connections between a limited number of texts. ${ }^{36}$

Sommer gee aan Eslinger toe dat meer aandag gegee moet word aan die sinkrone intertekstuele verbande in Bybeltekste. Hy hou egter vol dat ' $n$ benadering wat gefokus is op binne-Bybelse verwysing en eksegese ("inner-biblical allusion and exegesis") - soos dié van Fishbane -

32 FishBANE (1985:543).

33 Sien bv. die werk van LEVInSON (2008a; 2008b).

34 Sien bv. KLOUda (2004).

35 ESLINGER (1992:56).

36 SOMMER (1996:486-487). 
eweneens nodig is. Hy gee toe dat 'n mens nie kan ontkom aan die voorlopigheid van teorieë oor die relatiewe ouderdom van tekste en tekslae nie, maar dat dit nie impliseer dat 'n diakrone benadering by voorbaat faal nie. Hy som dit soos volg op:

To be sure, the need to perform historical analysis may place the critic in a precarious situation ... However, the proper response to such difficulties is not a flight to the synchronic ... Developing criteria to decide what parallels can be termed allusions, citations, or the result of influence is the project of the study of inner-biblical allusion and exegesis - a project I think possible, and whose methods need to be refined ... 37

Hierdie debat tussen Eslinger en Sommer beklemtoon twee belangrike punte. Eerstens, wanneer Bybeltekste vanuit 'n binne-Bybelse perspektief beskou word, veronderstel dit noodwendig ' $n$ diakrone benadering. Dat daar enigsins sprake is van herinterpretasie in veranderde kontekste noodsaak inagname van die historiese dimensie van die tekste. Al sou dit nie beteken dat daar tot spesifieke daterings van tekste en tekslae gekom word nie, moet daar minstens rekening gehou word met die breër verloop van die Literaturwerdung, oftewel die groeiprosesse in literatuur oor tyd heen. Hierdie groeiprosesse het egter nie eenduidig vanaf ouer na jonger materiaal verloop nie. Ouer materiaal kon ook weer in die lig van jonger materiaal aangepas en hersien word.

Tweedens beklemtoon hierdie debat ook dat terminologie dikwels vaag en onnoukeurig gebruik word. In die konteks van besprekings oor binne-Bybelse eksegese word noodwendig ook gebruik gemaak van verwante terminologie soos intertekstualiteit en verwysing (oftewel "allusion"). Die onderskeid dat intertekstualiteit vanuit die teks en leser gemotiveer word, terwyl binne-Bybelse uitleg en verwysing vanuit die outeur en teks gemotiveer word, lyk vir my nuttig. ${ }^{38}$ Dit beklemtoon dat daar een of ander vorm van intensionaliteit ${ }^{39}$ ter sprake is wat verband hou met die hertoe-eiening van oorgelewerde tradisies in nuwe, veranderde kontekste. Of die aansluiting by vroeëre tradisies eksplisiet gemaak word deur middel van verwysing ("allusion"), en of dit eerder meer implisiet gebeur deur die heropname, aansluiting, aanpassing of verandering van oorgelewerde tradisies (binne-Bybelse eksegese), lei tot 'n meer akkurate onderskeiding van terminologie.

Voordat ek 'n samevatting van hierdie afdeling aanbied, is dit ook interessant om daarop te wys dat studies oor binne-Bybelse uitleg (in albei kringe wat hierbo behandel is) meestal om drie Ou-Testamentiese tekskorpora draai:

37 SOMMER (1996:489).

38 "Intertekstualiteit" word soms ook as 'n sambreelterm gebruik om na alle vorme van die interafhanklikheid van tekste te verwys, met inbegrip van 'verwysing' en 'binne-Bybelse eksegese'. Hoewel insigte met betrekking tot intertekstualiteit hoofsaaklik met die algemene literêre wetenskappe (en die werk van Kristeva en Bakhtin in die besonder) geassosieer word, is daar heelwat studies wat hierdie terminologie en insigte vir die Bybelwetenskappe diensbaar wil maak. Een van hierdie studies, dié van Tull (2000:59) gee eksemplaries toe dat die gebruik van terminologie dikwels 'n mynveld is: "The concept of 'intertextuality', as the name implies, concerns interrelationships among texts. Thus far do theorists and practitioners concur, both in the area of biblical studies and in the wider world of literary theory. From this point on, however, the concept of intertextuality represents a battleground of differing emphases and claims, both linguistic and ideological." Sien ook die volgende studies: EDENBURG (2010), LoAder (2008), BAUTCH (2007), Schmid (2000), McKenZie (1999) en O’DAY (1999).

39 Hoewel ek deeglik bewus is van die sogenaamde "intentional fallacy" wat deur die New Criticism in histories-literêre interpretasie uitgewys is, is ek van mening dat ons nie sou kon ontsnap van die oorweging van die kategorie van intensionaliteit nie. Ek verstaan intensionaliteit egter nie as 'n individualistiese, psigologiese ingesteldheid van 'n outeur of outeurs nie, maar eerder as die kreatiewe wisselwerking tussen die resepsie en produksie van tekste in konkrete sosio-historiese omstandighede. 
- die herinterpretasie van die wetteversamelings van die Ou Testament, ${ }^{40}$

- $\quad$ van verskillende tradisies in die profetiese korpus-, ${ }^{41}$ asook

- die hersiening van die geskiedenis wat in die sogenaamde historiese boeke van die Ou Testament plaasvind ${ }^{42}$ (waaronder die herinterpretasie van Samuel-Konings deur Kronieke 'n baie prominente voorbeeld is).

Ter afsluiting van hierdie afdeling wil ek eers die vernaamste insigte wat vanuit die navorsingsoorsig geblyk het, opsom. Ek doen dit in ses punte:

(i) Omdat die ontstaansgeskiedenis van die Ou Testament oor verskeie eeue strek, kan aanvaar word dat veranderde kontekste die herbesoek van ouer, gesaghebbende tradisies sou meebring.

(ii) Resepsie van Bybeltekste begin nie eers nadat alle geskrifte voltooi is en ná kanonwording nie. Die resepsie van ouer tradisies vind reeds plaas tydens skrifwording, en die produksie van nuwe tekste was meestal die gevolg van die resepsie van ouer tradisies. Die outeurs en redaktors was dus in die eerste plek lesers.

(iii) Om enigsins hierdie insigte te kan verreken, is dit nodig om 'n diakrone perspektief in ons ondersoek van Bybeltekste in te sluit. ${ }^{43}$

(iv) Die eindproduk van hierdie groeiprosesse, naamlik die kanoniese gestalte waarin die tekste aan latere geloofsgemeenskappe oorgelewer word, doof nie die veelstemmigheid van die geïnkorporeerde herinterpretasieprosesse uit nie. Dit is juis ' $n$ verdere ontwikkeling van hierdie binne-Bybelse prosesse.

(v) Die hermeneutiese dinamika wat die Ou Testament tot stand gebring het, skep terselfdertyd die moontlikheid om in telkens nuwe omstandighede en kontekste opnuut met hierdie tekste in wisselwerking te tree. Sommer stel dit soos volg: "Biblical authors bequeathed their successors not only a text, but ways of relating to that text, reacting to that text, recreating that text, and allowing that text to remain alive". ${ }^{44}$

(vi) Binne-Bybelse uitleg het veral te make met daardie aanduidings wat in histories-gelaagde tekste gevind kan word van prosesse van herinterpretasie van oorgelewerde tradisies in nuwe en veranderde kontekste. Terwyl daar ook ander redes kan wees waarom daar veranderings in oorgelewerde tradisiemateriaal kan voorkom, het binne-Bybelse uitleg veral te make met daardie soort veranderings wat op groter skaal (en dus nie net in kleiner veranderings op woordvlak) aan oorgelewerde tradisies aangebring word om daarmee die ouer tradisies anders en relevant te dui vir die kontemporêre konteks van die leser.

In 'n volgende afdeling sal ek terugkeer na hierdie opsommende waarnemings. Ek wil egter nou eers hierdie insigte met ' $n$ aantal voorbeelde uit my Kronieke-navorsing illustreer.

3.

VOORBEELDE UIT DIE KRONIEKBOEKE

Uitleggers van die Kroniekboeke is in die uiters gelukkige posisie om toegang te hê tot die belangrikste Vorlagen van die boek (d.w.s. die tekste wat gebruik is in die totstandkoming van die boek). Die Kroniekskrywers, wat ons vir die moment as priesterlike literati uit die laat Persiese tydperk in die Jerusalem tempel identifiseer, ${ }^{45}$ het hoofsaaklik gebruik gemaak van geskrifte wat ook in die Ou-Testamentiese kanon opgeneem is, naamlik Samuel en Konings, maar ook Genesis

40 Sien as voorbeelde OtTo (1999; 2007) en LEVINSON (2008a; 2008b).

41 Sien as voorbeelde Steck (1996; 2001), Jeremias (1996) en Deist (1989).

42 Sien as voorbeelde WiLLi (1972) en KRATZ (1995).

43 Sien veral weer LOADER (2008) se pleidooi in hierdie verband.

44 SOMMER (2004:1829).

45 Sien bv. die bespreking van KLEIN (2006:13-17). 
en ander Pentateugmateriaal. Wanneer ons dus probeer vasstel hoe die Kroniekskrywers met hul brontekste omgegaan het, kan ons dit doen deur noukeurige vergelykings tussen die brontekste en Kronieke te maak, oftewel 'n sinopsis daarvan. Dit is dus nie vreemd dat Kronieke as 'n klassieke voorbeeld gebruik word om binne-Bybelse uitleg te illustreer nie.

In die navorsingsgeskiedenis van Kronieke is die boek aanvanklik redelik stief behandel. ${ }^{46}$ Onder invloed van die groot belangstelling in geskiedenis (as feitelike verslag van gebeurtenisse van die verlede) soos dit aan die einde van die 19e eeu gedefinieer is, het die boek algaande wel meer aandag begin kry om te probeer vasstel watter weergawe van die geskiedenis van $\mathrm{Ou}$ Israel die betroubaarste sou wees. ${ }^{47}$ Sedert die tweede helfte van die vorige eeu het daar egter 'n duidelik kentering in Kronieke-studies begin kom. Bybelwetenskaplikes het begin toegee dat albei historiografieë in die Ou Testament sogenaamde tendensieuse geskiedskrywing is, dit wil sê, geskiedenis wat met 'n bepaalde bedoeling en met sekere ideologiese voorveronderstellings weergegee word. ${ }^{48}$ Dit sou impliseer dat hierdie historiografieë elkeen in eie reg en in die raamwerk van hul eie voorveronderstellings ondersoek moet word. Hierdie verskuiwing het meegebring dat daar deesdae heelwat meer klem op die eiesoortige retoriek en teologie van Kronieke val, maar ook op die eiesoortige sosio-politieke konteks waarin dit tot stand gekom het.

Bybelwetenskaplikes het vroeg reeds die Kroniekboeke met latere Joodse Midrash-uitleg in verband gebring. Reeds die 19e-eeuse geleerde Julius Wellhausen het daarop gewys dat Kronieke die enigste boek van die Hebreeuse Bybel is waar die Hebreeuse woord midrash voorkom (in 2 Kron 13:22; 24:27). Die werkwoord waarvan die woord afgelei is, darash ("soek"), word ook baie prominent in die boek gebruik. "Om die Here te soek" is een van die duidelike teologiese lyne in die boek. Met die karakterisering van die boek as Midrash is reeds te kenne gegee dat Kronieke een of ander soort uitleg wou gee van die ouer geskiedenistradisie, soos vervat in die Deuteronomistiese geskiedenis.

Dit was egter in die 1970's dat die aandag duidelik begin verskuif het na die perspektief dat Kronieke 'uitleg' is. Die gepubliseerde proefskrif van Thomas Willi wat die hooftitel Die Chronik als Auslegung ("Kronieke as uitleg") dra, ondersoek die boek vanuit die perspektief dat die Kroniekskrywers interpreterend met hul historiese bronne omgegaan het, en hierdie interpretasie ten diens van hul konteks in Jerusalem in die laat Persiese tydperk wou doen. ${ }^{49}$

In my eie bestudering van Kronieke vind ek sterk aansluiting by twee leidende eksegete, naamlik Sara Japhet en Gary Knoppers, wanneer ek die boek as "Reforming History" beskryf. ${ }^{50}$ Die gebruik van hierdie beskrywing is doelbewus dubbelsinnig. Enersyds dui dit aan dat die Kroniekskrywers die oorgelewerde historiografiese tradisies wou hervorm ("reform") vanuit die insigte van hul nuwe, veranderde konteks. Hul beskrywing staan in kontinuïteit met die oorgelewerde tradisies, maar toon ook duidelike diskontinuïteite wanneer hulle die moed neem om die verlede effens anders te konstrueer as hul voorgangers. Andersyds beteken die frase "Reforming History" ook dat dit 'n soort geskiedskrywing is wat 'n verandering van denke (en teologiese beoordeling) oor die hede van die laat Persiese tydperk, maar ook oor die toekoms, wou teweegbring. Kronieke staan dus as't ware tussen die tye - tussen die verlede toe die Dawidiese monargie en Sionsteologie nog voor die ballingskap in takt was, en die hede waarin Jerusalem 'n onbeduidende hoofstadjie van 'n Persiese provinsie was. Die boek help die laat ná-ballingskapse geloofsgemeenskap in Jerusalem om opnuut na te dink oor hul identiteit

46 Sien die oorsigte van WiLli (2002) en Duke (2009).

47 Sien JAPHET (1985).

48 Sien besprekings in die vernaamste kommentare: KLEIN (2006), DiRKSEN (2005), KNOPPERS (2003;

2004); MCKENZIE (2004) en JAPHET (1993).

49 WiLLi (1972).

50 Sien veral JONKER (2007b). 
as Godsvolk in totaal veranderde sosio-politieke, sosio-ekonomiese en sosio-godsdienstige omstandighede. En hierdie nadenke word in kontinuïteit en diskontinuïteit met hul oorgelewerde tradisies gedoen. ${ }^{51}$

Hoe help hierdie beskouing van Kronieke nou om die boek te lees? Ek wil dit graag probeer illustreer deur twee voorbeelde van koningsgeskiedenisse te behandel: die beste en die slegste konings! Uitleggers van die Deuteronomistiese geskiedenis is dit eens dat die outeurs van daardie historiografie koning Manasse as die laagtepunt van die Dawidiese koningskap wou voorstel, terwyl koning Josia as die klimaks geïdealiseer word. ${ }^{52}$ Manasse was volgens 2 Konings 21 'n koning "wat net sleg gedoen het in die oë van die Here", en daar word gesuggereer deur die ballingskapse skrywers van die boek dat hy eintlik die grootste skuld moet dra vir die feit dat die Koninkryk van Juda deur die Babiloniërs vernietig is en in ballingskap weggevoer is. Josia, daarenteen, word in 2 Konings 22-23 voorgestel as die groot hervormer wat die tempel in Jerusalem laat restoureer het, en wat allerhande godsdienstige hervormingsmaatreëls ingestel het nadat die sogenaamde wetboek van die Here tydens die tempelrestourasie ontdek is. Hy word as die ideale koning voorgestel waarop die ballinge moet hoop vir herstel.

Hoe behandel die Kroniekskrywers hierdie twee konings? Ons begin met die beskrywing van die 'slegte' koning Manasse.

In 2 Kronieke 33:1-20 word die verhaal van koning Manasse vertel. Die Kroniekskrywers het gebruik gemaak van die vroeëre tradisie oor hierdie koning soos ons dit in 2 Konings 21:1-18 opgeteken vind. Betekenisvolle verskille kan tussen die twee weergawes bemerk word. Ek lys enkele van die grootste verskille:

Die Kroniekskrywers laat vers 11 tot 16 van 2 Konings 21 uit in hul weergawe. In daardie verse word Manasse geblameer vir al die godsdienstige afvalligheid wat in Jerusalem plaasgevind het en word dit baie duidelik gemaak dat die komende ballingskapsoordeel oor Jerusalem - wat soortgelyk sal wees aan wat Samaria getref het - hoofsaaklik Manasse se skuld is.

In die plek van die gedeelte wat uit die Koningsteks uitgelaat is, voeg die Kroniekskrywers egter hul eie materiaal in 2 Kronieke 33:11-17 in. In hierdie gedeelte word vertel hoe Manasse deur die Assiriërs in ballingskap geneem is, en dat hy daartydens hom voor die Here verootmoedig het deur tot Hom te bid, met die gevolg dat die Here hom vergewe en herstel het ( $v$ 11-13). Daarná gaan die gedeelte voort om aan te dui dat Manasse, toe hy na Jerusalem teruggekeer het, allerhande bouprojekte en godsdienstige hervormingsmaatreëls ingestel het (v 14-16). Die ingevoegde gedeelte eindig met ' $n$ aanduiding dat die volk steeds op sekere hoogtes geoffer het, maar net aan die Here hul God.

In 2 Kronieke 33:18 hervat die Kroniekskrywers weer die teks van 2 Konings 21:17, maar bring kleiner veranderings aan om aan te pas by die vermelding van Manasse se gebed (wat nie deur die Koningskrywers gerapporteer word nie). Die Kroniekskrywers brei in 2 Kronieke 33:19 verder uit om die gebed te beklemtoon.

Waarom hierdie verskille? Sommige uitleggers meen dat die Kroniekskrywers ongemaklik daarmee gevoel het dat Manasse enersyds aangedui word as die koning wat die langste oor Juda geregeer het (55 jaar - sien v 1), maar andersyds deur die Koningskrywers as die epitoom

51 Sien ook die volgende studies waarin ek die kwessie van identiteitsvorming in veranderde omstandighede prominent behandel: JONKER (2002; 2003a; 2003b; 2006; 2007a; 2008a; 2008b; 2008c; 2008d; 2009a; 2009b; 2010a; 2010b).

52 Sien bv. die bespreking in RÖMER (2007:158-163). Römer merk ten opsigte van Manasse op: "Manasseh belongs to the Deuteronomistic top list of the worst kings. Although he reigned for about 55 years, the Deuteronomists are only interested in his cultic counter reform, which annihilate (sic) the measures of Hezekiah" (2007:159). 
van boosheid voorgestel word. ${ }^{53}$ Die positiewer beeld van Kronieke sou dan ten doel hê om die relatiewe lang regering van Manasse te verduidelik. Ander studies sien egter heelwat meer in hierdie veranderings, weglatings en byvoegings. ${ }^{54}$ Ons is bewus van ' $n$ hele aantal buite-Bybelse geskrifte wat ook melding maak van Manasse. ${ }^{55}$ In twee Assiriese koningsrekords (Prisma A en B, onderskeidelik) word Manasse as 'n lojale vasaal voorgestel. In 'n aantal Joodse Pseudepigrafie uit die tweede Tempeltydperk word verwys na Manasse, onder andere ook in 'n geskrif getitel "Die gebed van Manasse", waarin die woorde van die gebed weergegee word. Nog 'n "gebed van Manasse" word weergegee in 'n fragment van 'n manuskrip wat tussen die Dooie Seerolle gevind is (4Q381 33). ${ }^{56}$ Daar bestaan eenstemmigheid dat die Joodse Pseudepigrafie met Manasse se gebed (wat in Grieks geskryf is) beslis baie later as die Kroniekboeke sy ontstaan gehad het, en moontlik selfs deur die Kronieketeks oor Manasse geïnspireer sou wees. Hoewel daar nie eenstemmigheid is of hierdie teks ' $n$ laat-Joodse of vroeg-Christelike oorsprong gehad het nie, meen uitleggers dat dit 'n poging was om te illustreer hoe God se vergifnis in die ou bedeling gefunksioneer het. Die Qumran-fragment bied egter ' $n$ interessante beskouing van Kronieke, deurdat sommige uitleggers aanvaar dat dit ' $n$ afskrif was van ' $n$ teks wat heelwat ouer sou gewees het - selfs ouer as Kronieke. Die moontlikheid bestaan dan dat hierdie ouer teks aan die Kroniekskrywers bekend sou gewees het, naas die weergawe van Manasse se regering soos ons dit in 2 Konings 21 vind. Die vraag bly dan steeds waarom die Kroniekskrywers hierdie gebed in hul teks sou insluit. 'n Redelik neutrale antwoord hierop sou wees dat hulle bloot hul teks wou bywerk met inligting wat dalk nie tot die vroeëre skrywers se beskikking was nie. Ons sou egter ook 'n mening kon waag wat juis illustreer dat die Kroniekskrywers ' $n$ herinterpretasie van hul oorgelewerde tradisies maak. Die veranderings aan die Manasse-verhaal is nie die enigste van hierdie soort in die Kroniekboeke nie. Sommige ander konings (bv. Asa) wat positief deur die Koningskrywers beoordeel word, kry in Kronieke weer sekere negatiewe kenmerke. ${ }^{57}$ Die teenoorgestelde gebeur met Manasse wat vanaf die epitoom van afvalligheid en die een wat blameer moet word vir die ballingskap verander word in ' $n$ boetvaardige koning wat vergifnis van die Here ontvang. As een stadium in die proses van ontwikkeling van die historiese tradisies van Ou Israel bemoei die Kronieketeks hom met sy eie tyd, terwyl dit tegelykertyd in wisselwerking tree met die beskikbare historiese tradisies wat kontinuïteit met die verlede verskaf. Die Koningsverhale word dus gebruik om 'n bepaalde boodskap in die kontemporêre sosio-historiese en sosio-religieuse konteks te bring - 'n konteks waarin die plek van die Jahwistiese monoteïsme bedink moes word te midde van die multigodsdienstige konteks van die Persiese Ryk. Die studie van Abadie interpreteer die Kroniekskrywers se weergawe van Manasse soos volg:

[O]ne sees how the theological writing of the chronistic narrative may be taken in a double manner, individually (through the experience of conversion of the king) and collectively (the exile of Israel and her restoration) without one interpretation excluding the other. By these theological and literary means, the Chronicler reintroduces the reality of Israel into the narrative, but in a completely different way than the deuteronomistic author in the book of Kings. It is less about realizing the reasons for the exile and its consequences, the collapse of the royal Davidic institution, than about suggesting to Israel that its return to the land depends on its return to God in faithfulness ... In this light, Manasseh appears with all his ambiguities as the reflection of Israel, the believing community that must always repent.

53 Sien die besprekings in JAPHET (1993:1002) en MCKenZIE (2004:353-354).

54 Sien bv. AbAdie (2003) en Hulbert (2008).

55 Hulbert (2008) se studie is veral nuttig om 'n oorsig te kry oor buite-Bybelse tekste waarin Manasse voorkom.

56 Sien SCHNIEDEWIND (1996).

57 Sien bv. my behandeling van die Asa-geskiedenis in Kronieke in JONKER (2006). 
One understands henceforth the theological choices made by the Chronicler that led him to engage in a complete rewriting of this figure's reign. ${ }^{58}$

Abadie se siening kom sterk ooreen met my voorstel dat die Kroniekskrywers primêr daarop ingestel was om deel te neem aan ' $n$ proses van identiteitsvorming gedurende die laat Persiese tydperk. ${ }^{59}$ Die Kroniekskrywers dra in die na-ballingskap tydperk daartoe by om - met verwysing na hul vroeëre historiografiese tradisies - na te dink oor die identiteit van "Die hele Israel" ('n frase wat baie prominent in die boek gebruik word). Hierdie identiteit word spesifiek godsdienstigteologies gedefinieer. "Die hele Israel" is dáárdie gemeenskap wat - te midde van die veranderde sosio-historiese omstandighede - die Here bly soek (darash) deur hulle aan hierdie God toe te wy. Dít vorm die grondslag van die Kroniekskrywers se kultiese en godsdienstige selfverstaan. Die herinterpretasie van die Manasse-verhaal vind dus plaas in die dinamiese wisselwerking tussen oorgelewerde tradisies (wat ons beskikbaar het in die Koningsboeke, maar ook ander tradisies oor die gebed van Manasse wat waarskynlik in omloop was) en 'n veranderde konteks.

Dit bring ons dan by die tweede voorbeeld, naamlik die goeie koning Josia. Verskeie uitleggers dui aan dat die verhaal van koning Josia in 2 Konings 22-23 die hoogtepunt van die Deuteronomistiese geskiedenis vorm. ${ }^{60}$ Josia word gesien as die vergestalting van 'n koning wat die Deuteronomistiese ideale nagestreef het.

Hoe word Josia in Kronieke behandel? Dit is eerstens betekenisvol hoe die Kroniekskrywers die makrostruktuur van die Josia-verhaal verander het. ${ }^{61}$ Deur bepaalde veranderings aan te bring aan hoe die Josia-verhaal in Konings gestruktureer is, slaag die Kroniekskrywers daarin om hul eie aksent op die verhaal af te druk. Maar, laat ons eers die Koningsverhaal in oënskou neem. Die verhaal in 2 Konings 22-23 word omraam deur 22:1 en 23:28-30, wat die gebruiklike inligting oor die regeringstyd van die koning bevat. In 22:2 volg dan 'n positiewe beoordeling van Josia in die tipies Deuteronomistiese styl en volgens die teologiese kriterium of hy goed of sleg gedoen het in die oë van die Here. Hierdie positiewe beoordeling word herhaal in 23:25-27, wat tesame met 22:2 'n raam vorm om die inhoud van die verhaal. Die inhoud val in twee eenhede uiteen. In 22:3-20 word Josia se opdragte om die tempel te restoureer gegee (v 3-7), word vertel van die vind van die "wetboek" tydens die restourasieproses (v 8-10) en word die koning se reaksie en die orakel van die profetes Hulda oor hierdie gebeure verskaf (v 11-20). Hierna volg die tweede eenheid in 23:1-24. Daarin word vertel hoe die koning en die volk die verbond met die Here hernieu het in die lig van die wetboek wat gevind is (v 1-3), hoe die koning allerhande kultiese hervormingsmaatreëls in Juda en Israel geïmplementeer het ( $v$ 4-20, 24a) en hoe daar vir die eerste keer "sedert die dae van die rigters" weer Paasfees gevier is (v 21-23, 24b).

Die Kroniekskrywers bring op hul beurt betekenisvolle veranderings aan die makrostruktuur van hierdie verhaal aan. ${ }^{62}$ Die verhaal van Josia in 2 Kronieke 34:1-36:1 word weer eens omraam met inligting wat, met kleiner aanpassings, uit die Koningsteks oorgeneem is (34:1 en 35:20-

58 ABADIE (2003:103-104).

59 Sien veral JONKER (2003b; 2007a; 2009a; 2010a).

60 RÖMER som dit soos volg op: "Josiah appears as the perfect king on all points. He represents the Deuteronomistic ideal of kingship. Monarchy could have had a future if kings behaved like Josiah and conformed to the Mosaic (Deuteronomistic) Law" (2007:161).

61 Die beskrywings van die makrostruktuur van die verhale wat hier aangebied word, is gedoen op grond van narratiewe en kommunikatiewe aanduidings in die Hebreeuse tekste. Die indeling in groter en kleiner eenhede geskied op grond van kommunikasiemerkers, soos tydsaanduidings, veranderings van plek, veranderings van karakters wat optree, ensovoorts. Die indeling is dus nie slegs inhoudelike aanduidings nie, maar wel aanduidings van die kommunikasiemerkers wat in die Hebreeuse tekste voorkom. Sien JONKER (2003a) vir 'n verduideliking van die tekspragmatiese uitgangspunte wat in hierdie analise gevolg is.

62 Sien die besprekings in JONKER (2002; 2003a; 2003b). 
36:1). Die sterfberig van die koning in die laaste gedeelte word egter betekenisvol anders vertelmaar hierna kom ek weldra terug. Na die openingsraam volg dan weer die positiewe beoordeling van die koning wat presies uit die ouer tradisie oorgeneem is (34:2). Die tweede beoordeling wat egter in die Koningsteks voorkom, word deur Kronieke weggelaat. Die Kroniekeverhaal se inhoud volg dan weer in twee eenhede. Die eerste (34:3-7) gee 'n aanduiding van die hervormingsmaatreëls van koning Josia. Hierdie weergawe is nie net heelwat bondiger as die ouer weergawe in Konings nie, maar dit staan ook in ' $n$ ander posisie in die verloop van die verhaal. Waar die Koningsteks suggereer dat die hervormingsmaatreëls een van die gevolge was van die vind van die wetboek in die tempel, laat die Kroniekskrywers hierdie maatreëls op inisiatief van koning Josia plaasvind deur dit voorop te stel. Die tweede groot hoofdeel van die Kroniekeverhaal volg nou daarná (34:8-35:19). Hierdie hoofdeel kan egter weer in drie kleiner eenhede verdeel word. In 34:8-18 word aangedui dat die restourasie van die tempel 'n uitvloeisel was van Josia se hervormingsmaatreëls (v 8-13), en dat die "wetboek van die Here" daartydens gevind is (v 14-18). ' $n$ Tweede onderdeel volg in 34:19-33, waarin die koning se reaksie en die Hulda-orakel (v 19-28), asook die verbondshernuwing, deur die koning en volk (v 29-33) ongeveer onveranderd uit die ouer tradisie oorgeneem is. Die derde onderdeel in 35:1-19 word volledig gewy aan die eerste viering van die Paasfees "sedert die dae van Samuel". Hierdie weergawe van die Paasfeesviering is nie net heelwat uitgebreider as die Koningsweergawe (wat slegs effe meer as drie verse hieraan wy) nie, maar daar word ook inhoudelik heeltemal ander inligting voorsien.

Nadat ons nou die veranderings in die makrostruktuur van die Josia-verhaal bekyk het, wil ek graag ook op twee kleiner aspekte van die Kroniekskrywer se eie materiaal wys. Die eerste is die terminologie wat met betrekking tot die offerande van die Paasfees in die laaste onderdeel van die verhaal gebruik word. In 35:13 word vermeld dat die paaslam "in vuur gekook"

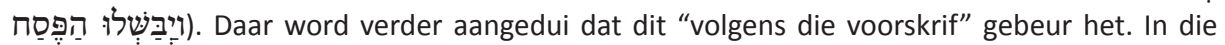
Pentateug-wetgewing is daar twee weergawes van die pasgavoorskrifte. In Eksodus 12:8-9, wat deel vorm van die voorskrifte vir die eerste Paasfees met die uittog uit Egipte, word pertinent aangedui dat die paaslam nie rou geëet mag word nie, en ook nie in water gekook mag word

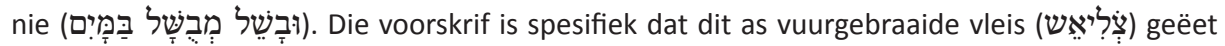
moes word. Die voorskrif in Deuteronomium 16:7 stipuleer egter dat dit gekook moes word

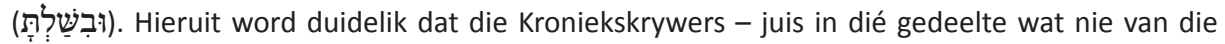
ouer Koningstradisie oorgeneem is nie - nie slegs van een voorskrif uit die Pentateug gebruik gemaak het nie, maar juis beide Torah-tradisies in hul aanduiding wou kombineer.

' $n$ Tweede betekenisvolle verandering in die verhaal kom in die sterfberig van koning Josia voor. Hoewel die Kroniekskrywers in die omraming aan die einde van die verhaal (35:20-36:1) van die ouer Koningstradisie gebruik gemaak het (2 Kon. 23:28-30), word die sterwe van Josia betekenisvol anders vertel. Die veldslag by Megiddo teen Farao Neko van Egipte word in die Koningsteks baie kort vermeld (v 29). In Kronieke word die berig egter uitgebrei, en word Farao Neko selfs 'n stem gegee. Volgens die Kroniekskrywers het hierdie Egiptiese koning die volgende deur 'n boodskapper aan Josia laat weet: “Ons het niks teen mekaar nie, koning van Juda! My veldtog is dié keer nie teen jou nie, maar teen 'n vyand. God het gesê ek moet gou maak. Moenie in God se pad kom nie. Hy is by my en Hy sal jou vernietig". ${ }^{4}$ Daar word verder berig dat Josia hom nie aan hierdie waarskuwing gesteur het nie, en dat hy toe in die veldslag met Neko gesneuwel het. Wat merkwaardig aan hierdie veranderde weergawe is, is dat koning Josia nie

63 Hierdie is my eie vertaling wat wel verskil van sowel die 1933- as die 1983- Afrikaanse vertalings, wat dit met "op/oor die vuur braai" vertaal. Hierdie vertalings het myns insiens nie raakgesien dat terminologie uit twee Pentateug-wetstradisies hier in een uitdrukking verenig word nie.

64 1983-Afrikaanse vertaling. 
net in 'n heelwat negatiewer lig geskets word nie, maar dat 'n Egiptiese koning hier voorgestel word dat hy namens God praat, terwyl die koning van Juda, die Godsvolk, nie hieraan gehoor gee nie.

Weer eens moet ons vra: Waarom hierdie verskille? Dit is duidelik dat die Kroniekskrywers met hul weergawe in kontinuïteit wou staan met die oorgelewerde historiografiese tradisies in die Deuteronomistiese geskiedenis, maar ook responsief wou wees in die veranderde konteks waarin die Dawidiese koningskap nie meer bestaan het nie, en waar 'n nuwe godsdienstigteologiese identiteit in die na-ballingskapse tydperk onder Persiese beheer gevorm moes word. My interpretasie van hierdie verhaal het ek elders soos volg gestel:

The new situation under Persian rule (without a Davidic king) would have prompted a new reflection on their traditions which presented the Davidic lineage as one of the foundation stones of their being an elected nation by Yahweh. The evaluations of these past kings by their older traditions were not altered. King Josiah is still ... a good king ... However, their rewriting of this king's history within the new context assigned a new function to this king. $\mathrm{He}$ is no longer viewed, as was the case in their older tradition, as the one epitomizing and legitimizing the Deuteronomistic theological tradition. Rather, he now serves the role of accentuating the cultic tradition (the Passover, in particular). It is not kingship that is at stake in the new situation, but cult. Who they were no longer primarily depended on having a Davidic king, but on the presentation and observance of their cultic traditions. These traditions are then described not in a nationalistic context, but in a universal sphere. The institution of the Passover is not in the first place particularistic, applying to Yahweh's people exclusively in opposition to other nations and their gods. It is rather an institution characteristic of Yahweh's people as part of a wider humanity. ${ }^{65}$

Kronieke idealiseer dus nie vir Josia as dié koning wat volgens Deuteronomistiese norme geregeer het nie. Josia word eerder geïnstrumentaliseer om aan te dui hoe die na-ballingskapse kultiese gemeenskap hul identiteit in die viering van die pasga moes vind, hoe hierdie gemeenskap die verskillende wetstradisies met mekaar moes verenig, en hoe hierdie kultiese gemeenskap hul plek moes vind in 'n wyer konteks wat deur konings uit ander nasies en 'n veelheid van godsdienste gedomineer word. Die Kroniekskrywers vind hul kontinuïteit in hul ouer oorgelewerde historiografiese tradisies, maar herinterpreteer en herformuleer hierdie tradisies sodanig dat dit responsief is ten einde hul godsdienstig-teologiese nadenke in ' $n$ radikaal veranderde konteks te fasiliteer.

Hoewel hierdie twee prominente voorbeelde, Manasse en Josia, met vele ander aangevul sou kon word, moet ek ter wille van ruimte hierby volstaan. Hierdie twee voorbeelde is egter genoegsaam om die volgende aan te dui:

Die Kroniekskrywers bring hul historiografiese werk tot stand in 'n sosio-historiese konteks wat dramaties verskil het van dié waarin die Deuteronomistiese geskiedenis gefinaliseer is.

In die veranderde omstandighede vind die Kroniekskrywers kontinuïteit in die oorgelewerde tradisies, en fasiliteer hulle hernude teologiese nadenke aan die hand van die oorgelewerde tradisies.

Die Kroniekskrywers was egter ook responsief in hul betrokke konteks, en skroom nie om uit vroeëre tradisies oor te neem, te verander, weg te laat en selfs by te voeg ten einde die nuwe konteks teologies te kan interpreteer nie.

Die Kroniekskrywers behandel die veelheid van wetsvoorskrifte vanuit die oorgelewerde wetstradisies (Deuteronomiese en Priesterlike tradisies) op sodanige wyse dat hulle hierdie verskillende tradisies met mekaar laat saamvloei ten einde hul kontinuïteit met albei aan te toon. 
Dit bring ons nou by die vraag wat in die subtitel van hierdie lesing geïmpliseer word: Watter hermeneutiese implikasies hou hierdie dinamika van (her)interpretasie in die Ou Testament vir teologie en kerk in? Of, om dit eenvoudiger te stel, watter riglyne vir ons eie interpretasie van die Skrif sou ons kon aflei uit die dinamika van (her)interpretasie wat aanleiding gegee het tot die totstandkoming van die Bybel?

\section{4.}

\section{HERMENEUTIESE IMPLIKASIES VIR TEOLOGIE EN KERK}

In die inleiding is reeds verwys na die talle kerklike en openbare debatte waarin die interpretasie van die Bybel in die spervuur staan. My waarneming is dat hierdie debatte dikwels gekenmerk word deur ' $n$ statiese begrip van hoe die Bybel in daardie debatte behoort te funksioneer. Sommige meen dat die Bybel 'n statiese grootheid is wat genoegsame gesag dra dat tydlose riglyne vir leer en lewe bloot daaruit afgelees kan word. Ander meen eweneens dat die Bybel 'n statiese grootheid is wat met verouderde en uitgediende voorstellings werk en daarom goedsmoeds geïgnoreer sou kon word. My oortuiging is dat hierdie debatte daarby sou kon baat om vir 'n oomblik terug te staan uit hierdie keiharde posisies en te let op die dinamiese hermeneutiek wat die Bybel tot stand gebring het, en wat in hierdie lesing geïllustreer is.

Hierdie dinamiese hermeneutiek is, eerstens, 'n hermeneutiek wat kontinuïteit met die oorgelewerde tradisies vind. Die (her)interpretasieprosesse vind plaas in 'n konteks waarin sekere getuienisse aangaande geloofsgemeenskappe se worsteling met die misterie van God reeds - juis deur middel van hierdie dinamiese prosesse - oor tyd heen gesaghebbende status aangeneem het. Die nadenke oor die misterie van God en God se handelinge met die mensdom begin nie in elke nuwe tydsgewrig van nuuts af nie. Geloofsgemeenskappe vind kontinuïteit met diegene wat hulle oor eeue heen voorafgegaan het.

'n Tweede kenmerk van hierdie hermeneutiek is dat dit 'n inklusiewe kanoniese hermeneutiek is. Vir Joodse en Christengelowiges het die oorgelewerde tradisies oor tyd heen ' $n$ bepaalde kanoniese gestalte aangeneem. Hierdie kanoniese gestalte weerspieël egter ' $n$ inklusiewe aard waarin die (her)interpretasieprosesse nie die geïnterpreteerde tradisies van ouds elimineer of verberg nie. Die gelaagdheid van tekste en die veelstemmigheid van die oorgelewerde en geïnterpreteerde tradisies word in die kanon gestalte gegee. Die kanoniese gestalte word daarmee, soos een outeur dit stel, "the sponsor for innovation". 66 Dit impliseer dan ook dat 'kanon' nie sinoniem met 'eenstemmigheid' kan wees nie, en ook nie met een finale, endvorm van die tekste gelykgestel moet word nie. 'n Inklusiewe kanoniese hermeneutiek sien die Bybelse kanon as ' $n$ dinamiese, veelstemmige gesprek wat voortstu vanaf die gryse verlede tot in die hede.

In die lig van bogenoemde punt is hierdie soort hermeneutiek derdens 'n diskursiewe hermeneutiek. Dit wil sê, die dinamika van (her)interpretasie vind plaas in 'n ruimte waarin 'n veelheid van stemme met mekaar in gesprek gebring word. Nie net die oorgelewerde tradisies konfronteer die gelowige interpreteerder met ' $n$ veelheid van perspektiewe nie; ook die kontekste waarin geïnterpreteer word, verskaf nuwe vrae en uitdagings. Die soort hermeneutiek wat die Bybel tot stand gebring het, sien hierdie veelheid van perspektiewe op God en die lewe voor die aangesig van God nie as bedreigend nie. Trouens, 'n diskursiewe hermeneutiek neem die uitgangspunt dat hierdie veelheid van perspektiewe juis nodig is om die onpeilbare rykdom en diepte van die misterie van God enigsins onder woorde te kan bring. Dit is juis in

66 Sien LEVINSON (2008a:89-94). Hy skryf met betrekking tot die kanon: "It invites innovation, it demands interpretation, it challenges piety, it questions priority, it sanctifies subversion, it warrants difference, and it embeds critique. Scholars across the humanities would benefit from deeper exploration of this rich paradox" (94). 
gesprekmatige verstaan dat nuansering en verryking moontlik is. Dit is in so ' $n$ verstaan waar gelowige interpreteerders aan hul eindige vermoë om tot finale kennis van God te kom, herinner word.

Die dinamika van (her)interpretasie impliseer, vierdens, 'n histories-kontekstuele hermeneutiek. Hierdie soort hermeneutiek neem deeglik in ag dat die Bybeltekste die produkte van oorlewering oor baie eeue heen is, en dat 'n diakrone beskouing van hierdie tekste onontbeerlik is. ' $n$ Histories-kontekstuele hermeneutiek herinner ons verder dat die oorgelewerde tradisies vanuit bepaalde sosio-historiese omstandighede gerig is. Daarom kan hierdie tradisies waarmee kontinuïteit gevind word nie konteksloos verstaan word nie. Hierdie soort hermeneutiek verg dus 'n sosio-historiese sensitiwiteit vir die omstandighede wat die oorgelewerde tradisies tot stand gebring het. Terselfdertyd beklemtoon hierdie soort hermeneutiek ook ' $n$ sosio-historiese sensitiwiteit vir die konteks waarin hierdie oorgelewerde tradisies (her)interpreteer word. Dit vermy interpretasies wat ' $n$ blote klakkelose herhaling van tradisies uit die verlede is sonder dat dit tot 'n nuwe verstaan in veranderde omstandighede aanleiding gee. Met hierdie soort hermeneutiese uitgangspunt staan die interpreteerder as't ware tussen die tye: enersyds wel deeglik veranker in die sosio-historiese kontekste van die verlede, maar andersyds ook veranker in die sosio-historiese kontekste waarin (her)interpretasie plaasvind.

'n Implikasie wat hieruit voortvloei, is vyfdens dat dit ook ' $n$ hermeneutiek van diskontuïteit is. Diegene wat betrokke was by die totstandkoming van die Bybel het die moed geneem om in hul veranderde omstandighede nuut en anders te interpreteer. Hierdie punt hef nie die eerste implikasie hierbo op nie. Diskontinuïteit en kontinuïteit met die oorgelewerde tradisies bestaan naas en gelyktydig met mekaar. Trouens, die dinamika van kontinuïteit EN diskontinuïteit met die oorgelewerde tradisies is juis die motor wat die tradisievormingsproses voortdryf. Kontinuïteit sonder diskontinuïteit het ' $n$ klakkelose herhaling van ou inhoude sonder relevansie vir die hede tot gevolg. Diskontinuïteit sonder kontinuïteit loop die ernstige gevaar om kort voor lank sig self af te skei en verwyder te raak van die oorgelewerde tradisies. In albei hierdie gevalle word die dinamiese aard van die tradisievormingsproses gedoof.

'n Sesde en laaste implikasie wat vloei uit hierdie studie van (her)interpretasie in die Bybel is dat 'n hermeneutiek waarin teks en teologie nie geskei word nie, benodig word. 'n Hermeneutiek wat die bestudering van die Bybeltekste aan die Bybelwetenskappe as voorstudie oorlaat, en dan pas daarná deur middel van die Sistematiese Teologie eers tot teologiese interpretasie sou kom, is onsensitief vir die feit dat die Bybeltekste as sodanig reeds eeue lange teologiese interpretasie en herinterpretasie saamdra. Die bestudering van die Bybeltekste in hul historiese gelaagdheid en saamgesteldheid vra reeds na die teologiese onderskeidings wat aanleiding gegee het tot die tekste se ontstaan. Teologie kan nie 'n blote sistematisering wees van tekstuele artefakte wat deur Bybelwetenskaplikes vanuit die tekste gemyn is nie. Bybelwetenskappe wat nie deeglik teologies van aard is nie, negeer die eng verband tussen teks en teologie. Eweneens negeer Sistematiese Teologie hierdie verband indien dit nie ook deeglike teksstudie inhou wat volledig rekening hou met die prosesse van (her)interpretasie in die Bybel nie. ${ }^{67}$

5.

SLOT: "LEWEND EN KRAGTIG"?

Is die Woord van God "lewend en kragtig" soos die Hebreërskrywer dit uitgedruk het?

In hierdie rede het ek die vraag vanuit Bybelwetenskaplike perspektief probeer beantwoord. Uiteraard is daar ook heelwat ander perspektiewe wat nodig is om hierdie uitspraak verantwoordelik te kan bedink, en ek nooi hiermee graag my kollegas in die ander teologiese

67 In hierdie siening sluit ek ten nouste aan by die standpunt van Eep Talstra. Sien TALSTRA (2003) en

TALSTRA \& OOSTING (2008). 
dissiplines om vanuit hul spesialisterreine hieroor saam te dink. Uiteraard moet daar gepraat word oor ons verstaan van die gesag en inspirasie van die Skrif in die lig van die prosesse van (her)interpretasie in die Bybel wat ek uitgewys het. En uiteraard moet deeglik besin word oor hoe ons die betrokkenheid van God se Gees by prosesse van interpretasie verstaan. Om hierdie kwessies te kan bedink, is egter nie die taak van 'n enkele dissipline nie.

Die antwoord wat ek deur hierdie rede op die vraag in die hooftitel wil gee, is ' $n$ ondubbelsinnige "Ja". Die Woord van God, verstaan as die selfverklaring van die misterieuse God in die wêreld van eindige mense, ís lewend en kragtig. Die dinamika van God se Woord is gesetel in die eeue lange nadenke in geloofsgemeenskappe oor wat dit beteken om voor die aangesig van die misterieuse God te leef, dié God wat nooit gepeil of gedefinieer kan word nie. Hierdie nadenke was deur die eeue nooit eenvoudig en eenvormig nie, en dit was nooit sonder nuanse nie. Hierdie nadenke het ook nie probeer om die veelstemmigheid van baie eeue uit te doof of stil te maak nie. Die Woord van God is lewend en kragtig omdat gelowiges oor eeue heen weens hul geloofsoortuiging die moed geneem het om - in kontinuïteit en diskontinuïteit met die oorgelewerde tradisies - in die lig van veranderde omstandighede te herinterpreteer.

\section{BIBLIOGRAFIE}

ABADIE, P (2003) "From the Impious Manasseh (2 Kings 21) to the Convert Manasseh (2 Chronicles 33): Theological Rewriting by the Chronicler", in GraHAM, MP et al. (ed.) The Chronicler as Theologian. Sheffield: Sheffield Academic Press, 89-104.

BAUTCH, R (2007) "Intertextuality in the Persian Period”, in BERQUIST, JL (ed.) Approaching Yehud: New Approaches to the Study of the Persian Period. Atlanta, GA: SBL, 25-35.

CARR, DM (2005) Writing on the Tablet of the Heart. Origins of Scripture and Literature. Oxford: Oxford University Press.

CLAASSEN, G (2007) Geloof, bygeloof en ander wensdenkery. Pretoria: Protea Boekehuis.

DEIST, FE (1989) "The Prophets: Are We Heading for a Paradigm Switch?", in FRITZ, V et al. (eds.) Prophet und Prophetenbuch. FS O. Kaiser. BZAW 185; Berlin: De Gruyter, 1-18.

DIRKSEN, PB (2005) 1 Chronicles. Leuven: Peeters.

DUKE, RK (2009) “Recent Research in Chronicles", Currents in Biblical Research 8/1, 10-50.

Edenburg, C (2010) "Intertextuality, Literary Competence and the Question of Readership: Some Preliminary Observations", JSOT 35/2, 131-148.

ESLINGER, L (1992) “Inner-biblical Exegesis and Inner-biblical Allusion: A Question of Category", VT 42, 47-58.

FISHBANE, M (1985) Biblical Interpretation in Ancient Israel. Oxford: Clarendon Press.

FISHBANE, M (1992) The Garments of Torah: Essays in Biblical Hermeneutics. Bloomington, IN: Indiana University Press.

FISHBANE, M (1998a) Biblical Text and Texture: A Literary Reading of Selected Texts. Oxford: Oneworld. FISHBANE, M (1998b) "The Hebrew Bible and Exegetical Tradition", in DE MooR, JC (ed.) Intertextuality in Ugarit and Israel. Leiden: Brill, 15-30.

FISHBANE, M (2003) "Canonical Text, Covenantal Communities, and the Patterns of Exegetical Culture: Reflections on the Past Century", in MAYES, ADH \& SALTERS, RB (eds.) Covenant as Context: Essays in Honour of EW Nicholson. Oxford: Oxford University Press, 135-161.

FISHBANE, M (2004) "Inner-Biblical Interpretation and the Development of Tradition", in OemING, M (ed.) Das Alte Testament und die Kultur der Moderne: Beiträge des Symposiums "Das Alte Testament und die Kultur der Moderne" anlässlich des 100. Geburtstags Gerhard von Rads (1901-1971), Heidelberg, 18-21 Oktober 2001. Münster: LIT Verlag, 25-35.

HULBERT, WG (2008) "Good King and Bad King: Traditions about Manasseh in the Bible and Late Second Temple Judaism", Stone-Campbell Journal 11/1, 71-81.

JAPHET, S (1985) "The Historical Reliability of Chronicles: The History of the Problem and its Place in Biblical Research", JSOT 33, 83-107.

JAPHET, S (1993) I \& / Chronicles. Louisville, KY: Westminster John Knox. 
Jeremias, J (1996) Hosea und Amos. Studien zu den Anfängen des Dodekapropheton. Tübingen: MohrSiebeck.

JoHnson, LT (2006) Hebrews: A Commentary. Louisville, KY: Westminster John Knox.

JONKER, LC (2002) “Completing the Temple with Josiah's Passover?” OTE 15/2, 381-397.

JONKER, LC (2003a) Josiah in the Chronicler's Mirror: Late Stages of the Josiah Reception in II Chr $34 f$. Gütersloh: Gütersloher Verlag.

JONKER, LC (2003b) "The Rhetorics of Finding a New Identity in a Multi-cultural and Multi-religious Society", VE 24/2, 396-416.

JONKER, LC (2006) “The Cushites in the Chronicler's Version of Asa's Reign: A Secondary Audience in Chronicles?" OTE 19/3, 863-881.

JONKER, LC (2007a) "Refocusing the Battle Accounts of the Kings: Identity Formation in the Books of Chronicles", in JONKER, LC et al. (eds.) Behutsames Lesen: Alttestamentliche Exegese im inderdisziplinären Methodendiskurs (FS Hardmeier). Leipzig: Evangelische Verlagsanstalt, 245-274.

JONKER, LC (2007b) "Reforming History: The Hermeneutical Significance of the Books of Chronicles", VT $57 / 1,21-44$.

JONKER, LC (2008a) “The Chronicler and the Prophets: Who were his Authoritative Sources?” SJOT 22/2, 275-295.

JONKER, LC (2008b) "The Chronicler's Portrayal of Solomon as the King of Peace within the Context of the International Peace Discourses of the Persian Era", OTE 21/3, 653-669.

JONKER, LC (2008c) “The Disappearing Nehushtan: The Chronicler's Reinterpretation of Hezekiah's Reformation Measures", ADPV 37, 116-140.

JONKER, LC (2008d) “Who Constitutes Society? Yehud's Self-understanding in the Late Persian Era as Reflected in the Books of Chronicles", JBL 127/4, 707-728.

JONKER, LC (2009a) "Textual Identities in the Books of Chronicles: The Case of Jehoram's history", in KNOPPERS, GN \& RISTAU, K (eds.) Community Identity in Judean Historiography: Biblical and Comparative Perspectives. Winona Lake, IN: Eisenbrauns, 197-217.

JONKER, LC (2009b) "The Exile as Sabbath Rest: The Chronicler's Interpretation of the Exile", in BECKING, B \& HUMAN, DJ (eds.) Exile and Suffering: A Selection of Papers Read at the 50th Anniversary Meeting of the Old Testament Society of South Africa OTWSA/OTSSA, Pretoria August 2007. Leiden: Brill, 213-229.

JONKER, LC (2010a) “David's Officials According to the Chronicler (1 Chronicles 23-27): A Reflection of Second Temple Self-categorization?" in JONKER LC (ed.) Historiography and Identity (Re)formation in Second Temple Historiographical Literature. London: T\&T Clark, 65-91.

JONKER, LC (2010b) "Revisiting the Saul Narrative in Chronicles: Interacting with the Persian Imperial Context?" OTE 23/2, 283-305.

KLEIN, RW (2006) 1 Chronicles. Minneapolis, MN: Fortress Press.

KLOUDA, SL (2004) “Applying Fishbane's Hermeneutical Strategies. Aggadic Exegesis in Matthew's Use of the Old Testament (Matthew 5:21-48)", Southwestern Journal of Theology 46/3, 19-30.

KNIGHT, D (1975) Rediscovering the Traditions of Israel. Missoula, MT: Scholars Press.

KNOPPERS, GN (2003) 1 Chronicles 1-9: A New Translation with Introduction and Commentary. New York: Doubleday.

KNOPPERS, GN (2004) 1 Chronicles 10-29: A New Translation with Introduction and Commentary. New York: Doubleday.

KRATZ, RG (1995) “Die Suche nach Identität in der nachexilischen Theologiegeschichte. Zur Hermeneutik des chronistischen Geschichtswerkes und ihrer Bedeutung für das Verständnis des Alten Testaments", in Mehlhausen, J (ed.) Pluralismus und Identität. Gütersloh: Gütersloher Verlag, 279-303.

LEVInson, B (2008a) Legal Revision and Religious Renewal in Ancient Israel. Cambridge: Cambridge University Press.

LEVINSON, B (2008b) "The Right Chorale": Studies in Biblical Law and Interpretation. Tübingen: MohrSiebeck.

LOADER, J (2008) "Intertextualität in geschichteten Texten des Alten Testaments", in WISCHMEYER, K \& SCHOLz, S (eds.) Die Bibel als Text: Beiträge zu einer textbezogenen Bibelhermeneutik. Tübingen/Basel: A. Francke Verlag, 99-119.

MCKENZIE, CS (1999) “Inner-biblical Interpretation, Hebrew Bible”, in HAYES, JH (ed.) Dictionary of Biblical Interpretation. Volume 1. Nashville, TN: Abingdon, 538-540. 
MCKeNZIE, SL (2004) 1-2 Chronicles. Nashville, TN: Abingdon.

Mollett, T; Grunduing, E \& VAn HeERDEN, E (2004) Die omstrede God: Bestaan God of nie? Stellenbosch: Rapid Access Publishers.

MOYISE, S (2001) The Old Testament in the New: An introduction. London: Continuum.

MOYISE, S (2008) Evoking Scripture: Seeing the Old Testament in the New. London: T\&T Clark.

O'DAY, GR (1999) "Intertextuality", in HAYES, JH (ed.) Dictionary of Biblical Interpretation. Volume 1. Nashville, TN: Abingdon, 546-548.

Oтто, E (1999) "Biblische Rechtsgeschichte als Fortschreibungsgeschichte", Biblia et Orientalia 56, 5-14.

Oтто, E (2007) "Scribal Scholarship in the Formation of Torah and Prophets: A Postexilic Scribal Discourse between Priestly Scholarship and Literary Prophecy", in KNOPPERS, GN \& LEVINSON, BM (eds.) The Pentateuch as Torah: New Models for Understanding its Promulgation and Acceptance. Winona Lake, IN: Eisenbrauns, 171-184.

PELSER, P (2005) NG Kerk: Reformeer of ... Disintegreer? Stellenbosch: Bybeldenke Uitgewers.

REVENTLOW, HG (2009) History of Biblical Interpretation. Volume 1: From the Old Testament to Origen (vertaal deur Leo G Perdue). Atlanta, GA: SBL.

RöMER, T (2007) The So-Called Deuteronomistic History: A Sociological, Historical and Literary Introduction. London: T\&T Clark.

SCHMID, K (2000) "Innerbiblische Schriftauslegung. Aspekte der Forschungsgeschichte", in KRATZ, RG et al. (eds.) Schriftauslegung in der Schrift: Festschrift für Odil Hannes Steck zu seinem 65. Geburtstag. Berlin: De Gruyter, 1-22.

SCHMID, K (2008) Literaturgeschichte des Alten Testaments: Eine Einführung. Darmstadt: Wissenschaftliche Buchgesellschaft.

SCHNIEDEWIND, W (1996) "A Qumran Fragment of the Ancient 'Prayer of Manasseh'?" ZAW 108, 105-107.

SOMmer, BD (1996) "Exegesis, Allusion and Intertextuality in the Hebrew Bible: A Response to Lyle Eslinger", VT 46, 479-489.

SOMMER, BD (2004) "Inner-biblical Interpretation", in BERLIN, B \& BRETTLER, MZ (eds.) The Jewish Study Bible. Oxford: Oxford University Press, 1829-1835.

STECK, OH (1996) Die Prophetenbücher und ihr theologisches Zeugnis: Wege der Nachfrage und Fährten zur Antwort. Tübingen: Mohr.

STECK, OH (2001) Gott in der Zeit entdecken: Die Prophetenbücher des Alten Testaments als Vorbild für Theologie und Kirche. Neukirchen-Vluyn: Neukirchener Verlag.

StendAHL, K (1984) "The Bible as a Classic, and the Bible as Holy Scripture", JBL 103/1, 3-10.

TALSTRA, E (2003) "Zou er ook wetenschap zijn bij de Allerhoogste?" (Psalm 73:11). Amsterdam: VU.

TALSTRA, E \& OOSTING, R (2008) "Jeremiah 32: A Future and its History: Actualisation in Writing and Reading", in DE WIT, JH \& WEST, GO (eds.) African and European Readers of the Bible in Dialogue: In Quest of a Shared Meaning. Studies of Religion in Africa 32. Leiden: Brill, 199-218.

TULL, PK (2000) "Intertextuality and the Hebrew Scriptures", CR: BS 8, 59-90.

VAN DER TOORN, K (2007) Scribal Culture and the Making of the Hebrew Bible. Cambridge, MA: Harvard University Press.

WILLI, T (1972) Die Chronik als Auslegung: Untersuchungen zur literarischen Gestaltung der historischen Ueberlieferung Israels. Göttingen: Vandenhoeck \& Ruprecht.

WILLI, T (2002) “Zwei Jahrzehnte Forschung an Chronik und Esra-Nehemia," ThR 67, 61-104.

\section{TREFWOORDE}

Hermeneutiek

Ou Testament

Kronieke

Binne-Bybelse eksegese

\section{KEY WORDS}

Hermeneutics

Old Testament

Chronicles

Inner-biblical exegesis
Prof Louis Jonker

Fakulteit Teologie

Universiteit van Stellenbosch

Privaatsak X1

7601 MATIELAND

E-posadres: Icj@sun.ac.za 